УДК 376-056.26 (075.8)

UDC 376-056.26 (075.8)

DOI: $10.31475 /$ ped.dys.2020.29.01

ЯН УТЬОСОВ,

аспірант

(Україна, Кам'янець-Подільський, Кам'янець-Подільський національний університет імені

Івана Огієнка,

вул. Івана Огієнка, 61)

YAN UTOSOV,

post-graduate student

(Ukraine, Kamianets-Podilskyi, Kamianets-Podilskyi Ivan Ohiienko National University,

Ivan Ohiienko St., 61)

ORCID: 0000-0002-3839-7803

ОЛЕНА УТЬОСОВА,

кандидат педагогічних наук

(Украӥна, Ужгород, Закарпатський інститут післядипломної педагогічної освіти,

вул. Волошина, 35)

OLENA UTOSOVA,

Candidate of Pedagogical Science

(Ukraine, Uzhhorod, Zakarpattia Institute of Postgraduate

Pedagogical Education,

Voloshyn St., 35)

ORCID: 0000-0001-5324-9334

\title{
Спеціальна методика формування соціальної компетентності підлітків 3 інтелектуальними порушеннями
}

\section{Special Method of Formation of Social Competence of Adolescents with Intellectual Disorders}

Робота присвячена питанням розвитку соціальної колпетентності у підлітків з інтелектуальними порушенняли в умовах освітнього процесу та в позакласній роботі. Визначено актуальність цього питання для соціалізації учнів закладів спеціальної та інклюзивної освіти. На основі теоретичного аналізу останніх досліджень з проблеми визначено суть, складові та чинники фбормування соціальної колпетентності. Обтрунтовано спеціальну методику форлування ї̈ у підлітків з інтелектуальними порушенняли. Спеціальна методика передбачае урахування можливостей кожного підлітка в умовах будь-яких змін педагогічних улов - від структури занять в класі до позакласної роботи, на будь-якому віковому етапі - від молодшого підліткового віку до юнацького. Представлена у статті спеціальна методика дозволить педагогам направляти корекиійну роботу з підлітками на фбормування в кожного окремого учня конкретних компетентностей, які важливі саме для нього на наступній ланці навчання та соціалізації. Для успішного впровадження заявленої спеціальної методики в практику роботи закладів спеціальної та інклюзивної освіти автором статті розроблено та структуровано основні принципи фоормування соціальної колпетентності підлітків з інтелектуальнили порушенняли, основані на освітніх стандартах нової украйнської школи (НУШ). У статті розкрито етапи та особливості впровадження спеціальної методики форлмування соціальних компетентностей у підлітків на заняттях $і$ в позакласній роботі.

Ключові слова: соціальна колпетентність, спеціальна методика, педагогічна модель, освітній процес, позакласна робота, інтелектуальні порушення.

Social competences are functional tasks related to social activities or social behavior that a teenager can successfully solve. In the article some important components of social competence are given. The scientific article deals with the problem of formation of social competence of teenagers with mental retardation. The basic concept of research is defined. The author understands the social competence as the mastering of the corresponding competence, including teenager's personal attitude to the subject of social activity or social behavior. The method assumes the formation of competencies that will allow within a sharp change of pedagogical conditions during the training period of the child at school, take into account the needs and capabilities of each student and guide the work on the specific competencies of 
each student, which is important on the next stage of training, by reorganization or the development. However social competences are the ability to build interpersonal relationships, have a joint activity, norms of behavior, communication in society, soft technologies, ability to work in team, under leadership, etc. The author scientifically substantiates the specifics of psychological and pedagogical influence on the social competence formation of teenagers with intellectual disorders. The article describes the main conditions and specifics of the special method for the formation of social competence of the teenagers. This is the formation of a strong and lasting active motive; the introduction of restrictive purposes; consistency and independence of action; consolidating the skills of actions moving into new conditions from lesson to extracurricular work, etc. For the successful integration of method in the system of education the author of the article has identified and developed the principles according to which this model will be possible to implement in practice. As a basis for the integration of case-method in the structure of secondary education, modern educational standards aimed at forming competencies are taken. The article contains a detailed description of the stages and application of the model on the formation of social competence of adolescents at school in curricular and extracurricular activities.

Key words: competence of adolescents, social competence, special method of formation of competences of adolescents, pedagogical model, educational process, lesson, extracurricular work, intellectual disorders.

Вступ / Introduction. Формування соціальної компетентності підлітків з інтелектуальними порушеннями - першочергове завдання нової української школи. Це обумовлено складністю протікання процесів соціалізації учнів спеціальних та інклюзивних закладів освіти. Формування соціальних компетентностей підлітків на кожному віковому етапі з урахуванням їх індивідуальних особливостей, здібностей, інтересів і потреб дозволить полегшити процес соціалізації та інтеграції в соціум підлітків з інтелектуальними порушеннями, дозволить їм самовизначитися, реалізуватися у професійно-трудовій сфері. Тому базою освітнього процесу таких дітей мають бути спеціальні методики, основані на принципах саме компетентнісного підходу (Акімова М., \& Козлова В., 2013, c. 23).

Сутність компетентнісного підходу у загальній психології та педагогіці розкрито у працях Г. Костюка, А. Мудрика та ін. Науковцями було досліджено питання сутності та змісту формування компетентності особистості як динамічного процесу іï соціалізації (М. Акімова, I. Бех, Н. Голованова, В. Козлова, В. Москаленко, А. Мудрик) (Акімова М., \& Козлова В., 2013); процесу самовизначення особистості, соціальних очікувань (І. Попович) (Попович I., 2019); педагогічних аспектів соціальної компетентності учнів (І. Шишменцев) (Шишменцев I., 2017).

Аналіз наукових праць сучасних вітчизняних i зарубіжних дослідників з проблеми формування соціальної компетентності (М. Акімова, Ю. Бистрова, В. Коваленко, Н. Колодна, I. Зимня, Л. Петровська, Г. Селевко, А. Хуторський, І. Шишменцев та ін.) дозволяе виділити спільні точки зору, пов'язані з використанням і тлумаченням поняття «соціальна компетентність», а саме: а) наукове розуміння поняття «компетентність» е багатоаспектним; б) розуміння поняття «соціальна компетентність» як ознаки, на підставі якої відбуваеться соціалізація особистості; в) визначення даної компетентності як індивідуальної якості особистості, яка володіє певними компетенціями, які дозволяють інтегруватися в соціум, формують ціннісні та моральні норми особистості, її ставлення до себе та інших. По суті, йдеться про сукупність якісних характеристик, що дозволяють системно здійснити педагогічний вплив на особистість з метою її інтеграції у суспільство.

Серед вітчизняних наукових праць особливо цікавими для нашого дослідження е роботи, присвячені формуванню соціальної компетентності в підлітковому віці. Так, М. Докторович розробила критерії сформованості соціальної компетентності підлітків з нормотиповим розвитком: самовизначення (сформованість власного «Я»), ціннісні орієнтації, самостійність, соціальна активність, саморегуляція, інтелектуальна лабільність, синергічність (Докторович М., 2007, с. 11).

У спеціальній психолого-педагогічній літературі проблема соціальної компетентності розглядалось у таких напрямках: сутність, зміст та характеристика соціалізації, соціальної адаптації, інтеграції та інклюзії осіб з інтелектуальними порушеннями (Т. Жулковська, Л. Занков, I. Лубовський, С. Миронова, В. Синьов, А. Шевцов); розвиток комунікативної діяльності та інформаційної компетентності підлітків 3 інтелектуальними порушеннями (Н. Гончарук, О. Проскурняк); психолого-педагогічний супровід, соціалізація та інклюзія учнів 3 із затримкою психічного розвитку, з порушеннями аналізаторів, опорно-рухового апарату (О. Глоба, С. Іванченко, В. Кобильченко, Т. Сак, Є. Синьова, Л. Ханзерук); педагогічні аспекти адаптації, соціалізації та соціальної інтеграції дітей 3 інтелектуальними порушеннями (А. Висоцька, В. Липа, Г. Мерсіянова); психолого-педагогічні основи соціалізації дітей з інтелектуальними порушеннями (І. Татьянчікова, О. Хохліна); професійно-трудова соціалізація та адаптація осіб 3 
інтелектуальними порушеннями (Ю. Бистрова, В. Бондар, О. Хохліна); особливості використання загальнокультурних норм поведінки учнями початкової та основної школи з інтелектуальними порушеннями (I. Бгажнокова, О. Вержиховська, Г. Запрягаєв); порушення соціальної поведінки та міжоособистісних стосунків учнів з інтелектуальними порушеннями (Е. Альбрехт, Т. Кузьміна, К. Лебединська, Г. Печерський, Л. Руденко). В тифлопедагогіці О. Архітко Л. Дрозд, Н. Колодною, розглядаються питання формування різних компетентностей у школярів з порушеннями зору в рамках програми Нової української школи (НУШ) - компетентність навчатися впродовж життя, природно-математична компетентність (Архитко О., \& Бистрова Ю., 2018, с. 11-17; Drozd L., \& Bystrova Y., 2020, с. 22-28). У олігофренопедагогіці О. Хохліна основними критеріями сформованості компетентності підлітків з інтелектуальними порушеннями вважае професійне самовизначення, самореалізацію та здатність самостійно робити професійний вибір (Drozd L., \& Bystrova Y., 2020, с. 56-61). Проблемі формування соціально-професійної компетентності присвячено праці Ю. Бистрової - автором визначено умови формування соціально-професійної компетентності випускників закладів спеціальної освіти, а саме - наявність системи психологопедагогічного супроводу професійно-трудової соціалізації учнів від початкової школи до закінчення освітнього закладу. Крім того, на основі аналізу змісту професійно-трудової компетентності дослідницею виділено низку параметрів визначених критеріїв. Кожний з них має три рівні розвитку, які характеризують вид мотивації (внутрішня чи зовнішня), професійну стійкість, усвідомленість власного вибору, самостійність прийняття рішення. Ю. Бистрова виділяе три рівні сформованості компетентності - недостатній, середній та оптимальний (Bystrova Y., 2019, c. 18). Рівні сформованості соціальної компетентності виділено також у дослідженні М. Докторович: оптимальний, адаптивний, індиферентний (Докторович М., 2007, с. 11).

Отже, аналіз літератури показав, що компетентність вчені розглядають як складне утворення, яке $є$ інтегрованим результатом навчання (засвоєння знань, формування умінь, навичок) та передбачае оволодіння учнем відповідними навчальними компетенціями, що включають його особистісне ставлення до них та предмету навчальної діяльності (О. Архитко, Ю. Бистрова, О. Гаврилов, М. Докторович, Л. Дрозд, С. Миронова, В. Синьов, С. Федоренко, О. Хохліна, М. Шеремет).

Соціальну компетентність ми будемо розглядати як індивідуальну якість особистості, яка володіе певними компетенціями, які дозволяють інтегруватися в соціум, формують ціннісні та моральні норми особистості, iㅣ ставлення до себе та інших (Bystrova Y., 2019). Соціальна компетентність дозволяе особистості розвиватися та бути успішною на побутовому, професійному, соціально-економічному, родинному та інших рівнях життя у соціумі (Drozd L., \& Bystrova Y., 2020).

Мета та завдання / Aim and Tasks. Мета - на основі принципів компетентнісного підходу розкрити сутність, зміст та етапи спеціальної методики формування соціальної компетентності підлітків з інтелектуальними порушеннями.

Завдання:

1. Розробити спеціальну методику застосування конкретних соціальних ситуацій (кейсів) для формування соціальних компетентностей у підлітків.

2. На основі ігор-драматизацій, елементів проектної діяльності, завдань планування та тренінгових занять створити конкретні проблемні соціальні ситуації (кейси) для позакласної роботи з підлітками, що мають інтелектуальні порушення.

3. Розкрити етапи застосування спеціальної методики.

4. Перевірити їі ефективність за допомогою статистичних даних.

Методи / Methods: теоретичні - аналіз та узагальнення теоретичних даних 3 метою визначення стану розробленості проблеми та перспективних напрямів їі вирішення. Емпіричні спостереження, опитування, метод кейсів (конкретних ситуацій). Статистичні: кількісна та якісна обробка результатів дослідження, порівняльний аналіз за критерієм Стьюдента для доведення значущості відмінностей між результатами до та після впровадження спеціальної методики.

Результати / Results. Дослідження проводилося на базі Чертезької спеціальної загальноосвітньої школи-інтернату I-II ступенів Закарпатської обласної ради, Горської спеціальної загальноосвітньої школи-інтернату I-II ступенів Луганської обласної ради. В експерименті взяли участь підлітки спеціальних закладів освіти, вік респондентів 13-15 років (51 хлопець і 63 дівчинки).

Для формування соціальної компетентності у підлітків з інтелектуальними порушеннями нами було створено спеціальну методику з використанням конкретних ситуацій у позакласній роботі для закріплення знань та навичок, отриманих на заняттях у школі. Підлітки розглядають ситуацію, знаходять шляхи їі вирішення за допомогою вчителя або самостійно, обговорюють їх, та приймають спільне рішення. 
Спеціальну методику було створено на основі принципів, які, на нашу думку, доцільно використовувати в рамках компетентнісного підходу:

1. Принцип взаємозв’язку різних способів освітньої діяльності (урок та позакласна робота).

2. Принцип системності, цілісності, послідовності та спадкоємності освітнього процесу в спеціальному закладі освіти.

3. Принцип відповідності методів навчання актуальним потребам НУШ.

4. Принцип особистісно орієнтованого навчання.

5. Принцип індивідуальності та самостійності прийняття рішень.

6. Принцип взаємодії та співпраці.

Наведені принципи було реалізовано за допомогою роботи з конкретними соціальними ситуаціями, які надавалися підліткам для розв'язання та закріплення знань, отриманих на заняттях в школі та виховних годинах, з метою формування в них соціальних компетентностей.

Спеціальна методика формування соціальних компетентностей на основі кейсів надае можливість ставити перед підлітками завдання та поетапно досягати результату їх виконання за рахунок вирішення проблемної ситуації. Основна мета спеціальної методики - створення педагогічних умов у позакласній роботі для цілеспрямованого, особистісно-оріентованого процесу формування у підлітків з інтелектуальними порушеннями соціальних компетентностей, що забезпечить їх успішну соціалізацію.

Кожна дитина розвиваеться в умовах успішної провідної діяльності. Спеціальна методика індивідуально підібраних кейсів дозволить забезпечити успішність їх виконання для всіх підлітків спеціального закладу освіти, незалежно від ступеню інтелектуального розвитку та супутніх порушень.

Реалізація спеціальної методики формування соціальних компетентностей включає:

- створення педагогами кейсу на матеріалі, вивченому на уроках в школі та підкріпленому практичними діями на позакласних заняттях;

- створення міжпредметних ситуацій, взаємозв'язок між предметами, взаємозв'язок між роботою в класі та позакласною роботою;

- актуалізація опірних знань та вмінь на уроках перед вирішенням кейсів;

- використання різних способів комунікації у системі учень-учень; учень-вчитель (роз'яснення, допомога, підтримка, медіація, показ дій, спільне проектування та планування);

- особистісний підхід при формуванні тренінгових груп для виконання завдань-кейсів;

- індивідуальна робота з кожним підлітком під час роз'яснення сутності завдання;

- індивідуальна мотивація;

- самостійна робота підлітків під час вирішення проблемної ситуації (за варіантами, наданими вчителем; самостійний вибір варіантів);

- варіативність завдань (декілька правильних рішень);

- показ алгоритмів вирішення складних завдань (конфліктних ситуацій, ситуацій фрустрації, ситуацій створення соціальних зв'язків);

- створення педагогами моделі комунікації та міжособистісного спілкування під час виконання завдань.

Етапи впровадження спеціальної методики:

1 етап - підготовчий - створення реальних соціальних ситуацій (кейсів) вчителями, методичного забезпечення для їх виконання.

2 етап - актуальний - підготовка підлітків для роботи з кейсами, створення тренінгових груп, активізація опірних знань на заняттях.

3 етап - формуючий експеримент - реалізація завдань на основі кейсів, ігри-драматизації, робота в команді, під керівництвом, пошук відповіді, презентація власних аргументів, прийняття рішення (самостійне, колективне).

4 етап - узагальнюючий - експертна оцінка сформованості соціальної компетентності за допомогою методів спостереження, анкетування, бесіди.

Алгоритм формування соціальної компетентності за допомогою нашої спеціальної методики: на першому етапі підліток сприймае ситуацію та надану інформацію. Завдання педагога - досягти розуміння ситуації підлітками за допомогою роз'яснень та питань. Наступний етап - підліток відтворюе інформацію. Далі - осмислення події, та розуміння, що недостатньо інформації, знань, вмінь та навичок для її вирішення, не має алгоритму самостійного вирішення ситуації. Підліток має зрозуміти, що для вирішення ситуації недостатньо компетенцій та звернутися по допомогу, змінити відношення до ситуації, знайти нові мотиви для їі вирішення. Останній етап - нове рішення ситуації, новий спосіб діяльності - нова компетентність.

Розвивальне середовище для формування компетентностей відіграе позакласна робота. Теоретичні знання, отримані на уроці можуть стати базою для вирішення соціальних ситуацій. А 
складні соціальні ситуації та відчуття успіху під час їх вирішення можуть стати мотивацією для навчання та отримання нових знань.

Для визначення рівня сформованості окремих компетентностей на узагальнюючому етапі було проведено порівняння самооцінки соціальних компетентностей підлітками з оцінками експертів (вчителів), які працювали з підлітками над кейсами у позакласній роботі. Це дозволило виділити відсоток підлітків, які оволоділи окремими компетентностями. Результати впровадження спеціальної методики - сформованість наступних соціальних компетентностей у підлітків за результатами спостереження та анкетування вчителів на узагальнюючому етапі - відображено в табл. 1.

Таблиия 1

Результативність сформованості у підлітків з інтелектуальними порушеннями соціальних компетентностей до та після впровадження спеціальної методики

\begin{tabular}{|c|c|c|c|}
\hline $\begin{array}{c}\text { Компе- } \\
\text { тентність }\end{array}$ & $\begin{array}{c}\text { До впровадження } \\
\text { спеціальної методики }\end{array}$ & $\begin{array}{c}\text { Після впровадження } \\
\text { спеціальної методики }\end{array}$ & $\mathrm{t} / \mathrm{p}$ \\
\hline 1 & $8,77 \%$ & $39,47 \%$ & $4,7 / 0,01$ \\
\hline 2 & $9,65 \%$ & $55,26 \%$ & $5,01 / 0,001$ \\
\hline 3 & $5,26 \%$ & $36,85 \%$ & $3,95 / 0,01$ \\
\hline 4 & $8,77 \%$ & $43,85 \%$ & $2,3 / 0,05$ \\
\hline 5 & $9,65 \%$ & $39,47 \%$ & $4,1 / 0,01$ \\
\hline 6 & $21,92 \%$ & $53,51 \%$ & $2,8 / 0,01$ \\
\hline 7 & $17,54 \%$ & $43,85 \%$ & $3,1 / 0,05$ \\
\hline 8 & $21,92 \%$ & $52,63 \%$ & $2,7 / 0,05$ \\
\hline 9 & $17,54 \%$ & $54,39 \%$ & $3,8 / 0,0$ \\
\hline
\end{tabular}

де 1 - це здатність самостійно працювати та планувати власну діяльність;

2 - здатність звертатися за допомогою, налагоджувати соціальні зв'язки або самостійно шукати інформацію для вирішення завдання;

3 - здатність переносити здобуті теоретичні навики в нові умови виконання завдань;

4 - здатність самостійно вибирати способи дій при вирішенні соціальних ситуацій;

5 - здатність працювати в команді;

6 - здатність вирішувати конфоліктні ситуації;

7 - здатність до цілепокладання та планування майбутніх дій;

8 - здатність до соціально схваленої поведінки та встановлення дружніх міжособистісних стосунків;

9 - здатність до компромісу та співпраці з однолітками та дорослими.

Отже, після проведення спеціальної методики значно підвищився рівень заявлених компетентностей у підлітків з інтелектуальними порушеннями. Особливо помітно підвисилася кількість підлітків 3 інтелектуальними порушеннями, які володіють здатністю самостійно працювати та планувати власну діяльність $(\mathrm{t}=4,7 ; \mathrm{p}=0,01)$; звертатися за допомогою ( $\mathrm{t}=5,01$; $\mathrm{p}=0,001)$; налагоджувати соціальні зв'язки; працювати в команді $(\mathrm{t}=4,1 ; \mathrm{p}=0,01)$.

Обговорення / Discussions. Аналіз наукових дефектологічних джерел дозволив виділити відмінності між окремими аспектами розгляду цієї проблеми та методиками формування соціальної компетентності у підлітків з інтелектуальними порушеннями.

Так в роботі I. Шишменцева наведено методику формування моральних компетентностей підлітків з інтелектуальними порушеннями на заняттях з української літератури (Шишменцева I., 2017, с. 12-19). Автор використовуе інтерактивні методи роботи з підлітками, впроваджуе елементи театральних вистав (Bystrova Y., 2019, с. 23-27). В дослідженнях Ю. Бистрової представлено методики формування професійно-трудової компетентності учнів спеціальних закладів освіти в рамках профоріентаційної роботи та тренінгу м'яких технологій (Bystrova Y., 2019). Авторка впроваджуе в практику роботи з підлітками, що мають інтелектуальні порушення, ігридраматизації, тренінги, обговорення ситуацій після перегляду фільмів на задану тематику (Bystrova Y., 2019). Методика кейсів ще не була об’єктом дослідження спеціальної освіти в аспекті формування компетентностей осіб з інтелектуальними порушеннями. Представлена нами авторська спеціальна методика використання конкретних соціальних ситуацій для формування соціальних компетентностей у підлітків з інтелектуальними порушеннями відрізняеться від традиційних методів, представлених у дослідженнях українських вчених, тим, що під час розв'язання кейсів учнями у вчителів $є$ можливість одночасно формувати будь-яку соціальну компетентність та контролювати рівень ї̈ сформованості у підлітка. Крім того, вперше у практиці корекційної освіти розвивальним середовищем для формування компетентностей нами заявлено не корекційні заняття, а саме позакласна робота. 
Висновки / Conclusions. Таким чином, у статті на основі теоретичного аналізу літератури встановлено, що незважаючи на актуальність проблеми формування соціальних компетентностей у підлітків з інтелектуальними порушеннями, вона є недостатньо розробленою як у теоретичному, так і в практичному аспектах. Тому було розроблено та впроваджено спеціальну методику формування соціальних компетентностей на основі створення реальних соціальних ситуацій (кейсів) у позакласній роботі. Представлена у статті спеціальна методика дозволить педагогам направляти корекційну роботу з підлітками на формування в кожного окремого учня конкретних компетентностей, котрі важливі саме для нього на наступній ланці навчання та соціалізації. Для успішного впровадження заявленої спеціальної методики в практику роботи закладів спеціальної та інклюзивної освіти автором статті розроблено та структуровано основні принципи формування соціальної компетентності підлітків з інтелектуальними порушеннями, основані на освітніх стандартах нової української школи. Отримані після впровадження спеціальної методики результати психолого-педагогічного вивчення засвідчили ефективність її використання для у підлітків з інтелектуальними порушеннями в умовах спеціальних закладів освіти.

Проведене дослідження не вичерпуе всіх аспектів проблеми формування соціальної компетентності у підлітків з інтелектуальними порушеннями. Подальшого вивчення потребують питання формування компетентності у окремих сферах самореалізації та соціалізації особистості, зокрема, у професійній, формування необхідних соціальних та операційних, технологічних компетентностей, необхідних для вибору професійного шляху після закінчення школи та досягнення професійної мети. Наступним кроком наших наукових пошуків в цьому напрямку буде дослідження питань формування соціальних компетентностей підлітків 3 інтелектуальними порушеннями на основі професійно-трудових, технічних, правових та економічних кейсів.

\section{Список використаних джерел і літератури:}

Акимова, М. К., \& Козлова, В. Т. (2013). Психофизиологические особенности индивидуальности школьников. Учет и коррекиия. Москва [in Russian].

Архитко, О. В. \& Бистрова, Ю. О. (2018.) Дослідно-експериментальна робота 3 дормування природничо-математичних компетентностей учнів з особливими освітніми потребами. Науковий часопис Національного педагогічного університету імені М. П. Драгоманова, 36, 11-17 [in Ukrainian].

Докторович, М. О. (2007). Формування соціальної компетентності старшого підлітка з неповної сім $\imath$. (Автореф. дис... канд. пед. наук). Інститут проблем виховання АПН України. Київ [in Ukrainian].

Попович, І. С. (2019). Психологія соціальних очікувань особистості: методологія, теорія і практика: навч.-метод. посіб. Херсон [in Ukrainian].

Хохліна, О. П. (2018). Психолого-педагогічні основи корекційної спрямованості трудового навчання учнів з вадами розумового розвитку. Київ [in Ukrainian].

Шишменцев, І. М. (2017). Виховання культури людських взаемин у розумово відсталих старшокласників засобами української літератури. (Автореф. дис. ... канд. пед. наук). Нацоцінальний педагоггчний університет імені М. П. Драгоманова. Київ [in Ukrainian].

Bystrova, Y. (2019). Behaviour Peculiarities of Adolescents with Intellectual Disabilities in Conflict Situations. Modern Research of the Representatives of Psychological Sciences: Collective monograph. Lviv-Torun: Liha-Pres [in English].

Drozd L., \& Bystrova Y. (2020). Features of Communication of Adolescents with Intellectual Disabilities in the Interpersonal Relations. Insight: the Psychological Dimensions of Society, 9, 123-133 [in English].

\section{References:}

Akimova, M. K., \& Kozlova, V. T. (2013). Psixofiziologicheskie osobennosti individual'nosti shkol'nikov. Uchyot $i$ korrekciya [Psychophysiological Characteristics of the Individuality of Students. Recording and Correction]. Moscow [in Russian].

Arkhytko, O. V. \& Bystrova, Yu. O. (2018). Doslidno-eksperymentalna robota z formuvannia pryrodnychomatematychnykh kompetentnostei uchniv z osoblyvymy osvitnimi potrebamy [Experimental Work on the Formation of Natural and Mathematical Competencies of Students with Special Educational Needs]. Naukovyi Chasopys Natsionalnoho Pedahohichnoho Universytetu imeni M. P. Drahomanova - Scientific Bulletin of National Pedagogical Dragomanov University, 36, 11-17 [in Ukrainian]

Doktorovych, M. O. (2007). Formuvannia sotsialnoi kompetentnosti starshoho pidlitka $z$ nepounoi simi [Formation of Social Competence of the Senior Teenager From a Single-Parent Family]. (Extended abstract of Candidate's thesis). Kyiv [in Ukrainian].

Popovych, I. S. (2019). Psykholohiia sotsialnykh ochikuvan osobystosti: metodolohiia, teoriia i praktyka [The Psychology of Social Science: Methodology, Theory, and Practice]. Kherson [in Ukrainian].

Khokhlina, O. P. (2018). Psykholoho-pedahohichni osnovy korektsiinoi spriamovanosti trudovoho navchannia uchniv z vadamy rozumovoho rozvythu [Psychological and Pedagogical Foundations of the Correctional Orientation of Labor Education of Students with Intellectual Disabilities]. Kyiv [in Ukrainian].

Shyshmentsev, I. M. (2017). Vykhovannia kultury lyudskykh vzaiemyn u rozumovo vidstalykh starshoklasnykiv zasobami ukrainskoi literatury [Upbringing Culture of Human Relations of Mentally Retarded Senior Pupils by Means of Ukrainian Literature]. (Extended abstract of Candidate's thesis). Kyiv [in Ukrainian]. 
Bystrova, Y. (2019). Behaviour Peculiarities of Adolescents with Intellectual Disabilities in Conflict Situations. Modern Research of the Representatives of Psychological Sciences: Collective monograph. Lviv-Torun: Liha-Pres [in English].

Drozd L., \& Bystrova Y. (2020). Features of Communication of Adolescents with Intellectual Disabilities in the Interpersonal Relations. Insight: the Psychological Dimensions of Society, 9, 123-133 [in English].

Дата надходження статті: «13» серпня 2020 р.

Стаття прийнята до друку: «22» вересня 2020 р.

Утьосов Ян - аспірант кафедри корекційної педагогіки та інклюзивної освіти Кам'янець-Подільського національного університету імені Івана Огієнка

Utosov Yan - Post-Graduate Student of the Department of Correctional Pedagogy and Inclusive Education of Kamianets-Podilskyi Ivan Ohiienko National University

Утьосова Олена - старший викладач кафедри суспільно-гуманітарної та етико-естетичної освіти Закарпатського інституту післядипломної педагогічної освіти, кандидат педагогічних наук

Utosova Olena - Senior Lecturer of the Department of Social-Humanitarian and Ethical-Aesthetic Education of Zakarpattia Institute of Postgraduate Pedagogical Education, Candidate of Pedagogical Sciences

\section{Цитуйте иљю статтю як:}

Утьосов, Я., \& Утьосова, О. (2020). Спеціальна методика формування соціальної компетентності підлітків 3 інтелектуальними порушеннями. Педагогічний дискурс, 29, 7-13. doi: 10.31475/ped.dys.2020.29.01.

\section{Cite this article as:}

Utosov, Ya., \& Utosova, O. (2020). Special Method of Formation of Social Competence of Adolescents with Intellectual Disorders. Pedagogical Discourse, 29, 713. doi: 10.31475/ped.dys.2020.29.01. 